\title{
Research-Based Guidelines for Marketing Information Systems
}

\author{
Albérico Travassos Rosário, University of Aveiro, GOVCOPP - ESGTS - IPSantarém, Portugal \\ (iD) https://orcid.org/0000-0003-4793-4110
}

\begin{abstract}
Marketing information systems (MKIS) are decision support systems focused on specific marketing decisions, providing a more efficient and effective framework for analyzing and identifying changes in the market environment. The literature review reveals that there are gaps in theoretical and empirical studies about which specific steps and best practices should be considered in MKIS implementation efforts. Is it intended to synthesize the knowledge and perceptions generated by existing MKIS studies and identify the generic and particular guidelines that can be derived from the existing body of MKIS research. A review of the literature leads the authors to a thematic synthesis that generates five core guidelines for MKIS: (1) developing, implementing, and measuring the effectiveness of the MKIS; (2) how to align the MKIS with organizational strategy and decision-making; (3) leveraging the MKIS resources in internet marketing; (4) generating and applying marketing intelligence; and, finally, (5) leveraging the benefits of the MKIS in terms of accumulating knowledge and marketing intelligence.
\end{abstract}

\section{KEYWORDS}

Marketing, Marketing Information System, Marketing Intelligence Decision Support Systems, MIS, MKIS

\section{INTRODUCTION}

Marketing information systems (MKIS) have constituted a focal theme in academic and practitioner research for well over five decades. The MKIS concept has, thus, attracted a wide spectrum of definitions and conceptualizations in the available body of scholarly literature. However, all conceptualizations appear to converge upon the common definitional consensus that MKIS are management information systems (MIS) formulated specifically to support a firm's marketing strategy and decision-making (Mandal, 2018; Wahyuni \& Lestari, 2020). Accordingly, the quintessential MIS contains four core components, namely, internal reporting systems that organize and collate a firm's internal records with immediate value to marketing decisions; marketing research systems, which 
are constituted of monitoring and tracking exercises designed purposefully to address well-defined marketing problems; marketing intelligence systems consisted of data sources and procedures to extract decision-making information from the marketing environment; and, fourthly, marketing models that act as the mechanism for interpreting marketing intelligence for application to strategic marketing (Ashmarina \& Zotova, 2016; Sigauke, 2019; Martell, 2018). MKIS are particularly necessary for contemporary organizations because these systems provide the most effective frameworks for monitoring changes within the external market environment, such as shifting factors of consumer behavior, industry competition, government policies, technology, and economic conditions (Perreault, 2018). The overarching and fundamental benefit derived from the implementation of MKIS derives, therefore, from the fact that they facilitate the acquisition of knowledge, agility, and flexibility in modern firms' responses to changes in the external business and marketing environments.

Despite the existence of a robust body of pertinent literature, a preliminary review of the available research reveals that very few theoretical and empirical studies attempt to provide comprehensive guidelines on the implementation of MKIS. There appears to be a significant gap in the current body of knowledge concerning the question of what specific steps and best practices contemporary firms should consider in their efforts to implement MKIS (Perreault, 2018). The current paper's core objective, in this regard, is to synthesize the knowledge and insights generated by extant studies. We have compiled the most cited peer-reviewed literature on the topic, summarizing the current approach. Such a synthesis would be valuable in linking the meaningful yet disparate pieces of evidence generated by high-quality articles on MKIS that are presently available. This discussion's epistemological perspective is, therefore, guided by the research question: what generic and specific guidelines can be derived from the extant body of research into marketing information systems?

\section{METHODOLOGICAL APPROACH}

To answer the research question, the paper explores relevant literature sourced from the SCOPUS database in August 2020. SCOPUS is the most important peer-reviewed database of scientific articles in the academic world. However, we consider that the study has a limitation of only considering the SCOPUS database, thus excluding other academic databases.

Thus, we proceeded as follows: (i) definition of the research question; (ii) location of the studies; (iii) selection and evaluation of the studies; (iv) analysis and synthesis; (v) presentation of the results; and (vi) discussion and conclusion of the results. This methodology ensures that the review is comprehensive, auditable and replicable and answers the research question (Rosário et al., 2020; Rosário \& Cuz, 2019; Sacavém, et al., 2019).

The bibliographic search included peer-reviewed, scientific articles published between January 1991 and August 2020. The literature search was delimited to the subject areas of business, management, and accounting; and the keywords: "marketing," "management," "management information systems," "MIS," "marketing information systems," "MKIS," "marketing research systems," "marketing intelligence," "marketing models," and "decision support systems." The search process generated 19 articles that are subsequently reviewed herein in narrative fashion to facilitate more in-depth and elaborate article-specific analyses, and the eventual derivation of shared themes that answer the paper's research question directly (Rosário et al., 2020; Rosário \& Cuz, 2019; Sacavém, et al., 2019). Table 1 shows the details and characteristics of the evidence source.

The subsequent findings generated by the review process are presented in a narrative form, in order to allow an in-depth analysis of each article chosen in its central themes.

Consequently, the subsequent section 'theoretical perspectives' presents the results of the narrative review and the section 'discussion of the topics' conducts a thematic synthesis that generates five central guidelines for MKIS. 
Table 1. Evidence source details and characteristics

\begin{tabular}{|c|c|c|}
\hline investigator(s) & Title & $\operatorname{Approach}(\mathbf{s})$ \\
\hline Buttert \& Tamaschke (1996) & $\begin{array}{l}\text { The use and development of marketing } \\
\text { information systems in Queensland, Australia. }\end{array}$ & $\begin{array}{l}\text { marketing information system (MKIS) can make } \\
\text { decision making more efficient and effective. }\end{array}$ \\
\hline Gounaris, et al. (2007) & $\begin{array}{l}\text { Measuring the effectiveness of marketing } \\
\text { information systems: An empirically validated } \\
\text { instrument. }\end{array}$ & $\begin{array}{l}\text { design and empirically validate an instrument } \\
\text { to measure the effectiveness of an intelligence } \\
\text { marketing system. }\end{array}$ \\
\hline Chatzipanagiotou \& Coritos (2010) & $\begin{array}{l}\text { A suggested typology of Greek upscale hotels } \\
\text { based on their MrkIS: Implications for hotels' } \\
\text { overall effectiveness. }\end{array}$ & $\begin{array}{l}\text { effectiveness of MKIS and its influence on the } \\
\text { adoption of specific measures. }\end{array}$ \\
\hline Xu (1999) & $\begin{array}{l}\text { The strategic orientation of marketing information } \\
\text { systems - an empirical study. }\end{array}$ & $\begin{array}{l}\text { the practice of the strategic function of marketing, } \\
\text { and the application of information systems in } \\
\text { supporting the strategic function. }\end{array}$ \\
\hline Higby \& Farah (1991) & $\begin{array}{l}\text { The status of marketing information systems, } \\
\text { decision support systems and expert systems in } \\
\text { the marketing function of U.S. firms. }\end{array}$ & $\begin{array}{l}\text { status of MKIS, Decision Support Systems, and } \\
\text { Expert Systems. }\end{array}$ \\
\hline Li (1995) & $\begin{array}{l}\text { Marketing information systems in the top U.S. } \\
\text { companies: A longitudinal analysis. }\end{array}$ & $\begin{array}{l}\text { determine the overall status of MKISs in top U.S. } \\
\text { companies. }\end{array}$ \\
\hline Li, et al. (1993) & $\begin{array}{l}\text { Marketing information systems in the fortune } 500 \\
\text { companies: Past, present, and future. }\end{array}$ & $\begin{array}{l}\text { concept of a management information system } \\
\text { MKIS. }\end{array}$ \\
\hline Lackman, et al. (2000) & $\begin{array}{l}\text { The contribution of market intelligence to tactical } \\
\text { and strategic business decisions. }\end{array}$ & market intelligence as a successful strategy. \\
\hline Ashill \& Jobber (2001) & $\begin{array}{l}\text { Defining the information needs of senior } \\
\text { marketing executives: An exploratory study. }\end{array}$ & $\begin{array}{l}\text { design is the identification of the marketing } \\
\text { information needs of decision-makers. }\end{array}$ \\
\hline Hess, et al. (2004) & $\begin{array}{l}\text { Geographic information systems as a marketing } \\
\text { information system technology. }\end{array}$ & $\begin{array}{l}\text { analyze the technical resources of geographic } \\
\text { information systems (GIS) and show how these } \\
\text { resources align with the elements of MKIS. }\end{array}$ \\
\hline Heinen (1996) & Internet marketing practices. & $\begin{array}{l}\text { explores how companies are - or will be - using the } \\
\text { Internet to improve marketing. }\end{array}$ \\
\hline Rowley (1999) & $\begin{array}{l}\text { Loyalty, the Internet and the weather: The } \\
\text { changing nature of marketing information } \\
\text { systems? }\end{array}$ & $\begin{array}{l}\text { development of the significance of customer } \\
\text { databases in marketing. }\end{array}$ \\
\hline Vazquez (2019) & $\begin{array}{l}\text { Effects of enduring involvement and perceived } \\
\text { content vividness on digital engagement. }\end{array}$ & $\begin{array}{l}\text { compares digital engagement produced by BCs of } \\
\text { retailers at levels of cognitive load. }\end{array}$ \\
\hline$-*(2002)$ & $\begin{array}{l}\text { Britannia discovers the benefits of analytical } \\
\text { CRM. }\end{array}$ & benefits of analytical CRM. \\
\hline Marsden (1998) & $\begin{array}{l}\text { Memetics: A new paradigm for understanding } \\
\text { customer behaviour and influence }\end{array}$ & $\begin{array}{l}\text { a non-technical introduction to the science of } \\
\text { memetics and to suggest how this new discipline } \\
\text { may be applied to the design and development of } \\
\text { effective marketing campaigns. }\end{array}$ \\
\hline Li, et al. (1999) & $\begin{array}{l}\text { A framework for a hybrid intelligent system in } \\
\text { support of marketing strategy development }\end{array}$ & $\begin{array}{l}\text { A framework for a hybrid intelligent support } \\
\text { system is proposed of computer-based support } \\
\text { systems and computer-based systems in developing } \\
\text { marketing strategy. }\end{array}$ \\
\hline Le Bon, \& Merunka (2006) & $\begin{array}{l}\text { The impact of individual and managerial factors } \\
\text { on salespeople's contribution to marketing } \\
\text { intelligence activities. }\end{array}$ & $\begin{array}{l}\text { salespeople's motivation and commitment to } \\
\text { marketing intelligence effort. }\end{array}$ \\
\hline Watson \& McKeown (1999) & $\begin{array}{l}\text { Manheim Auctions: Transforming } \\
\text { Interorganizational Relationships with an } \\
\text { Extranet. }\end{array}$ & $\begin{array}{l}\text { adoption strategies for an extranet and describes } \\
\text { how to assess a disintermediation threat. }\end{array}$ \\
\hline McIntyre \& Sutherland (2002) & $\begin{array}{l}\text { A critical analysis into the accumulation of } \\
\text { marketing knowledge at the level of the firm. }\end{array}$ & $\begin{array}{l}\text { belief that a problem correctly identified is a } \\
\text { problem half solved, to the accumulation of } \\
\text { marketing knowledge at the level of the firm. }\end{array}$ \\
\hline
\end{tabular}

Note: *data not available.

Source: original source

\section{PUBLICATION DISTRIBUTION}

Peer-reviewed articles on the topic can be traced as back as 1991. With the exception of 2010 and 2019, there has been peer-reviewed literature on the topic in a consistent yearly basis 1999 was the year with the largest amount of peer-reviewed articles on the topic, amounting to 4 . 
Figure 1 summarizes the published peer-reviewed literature for the 1991-2020 period.

Figure 1. Documents by year (Source: own elaboration)

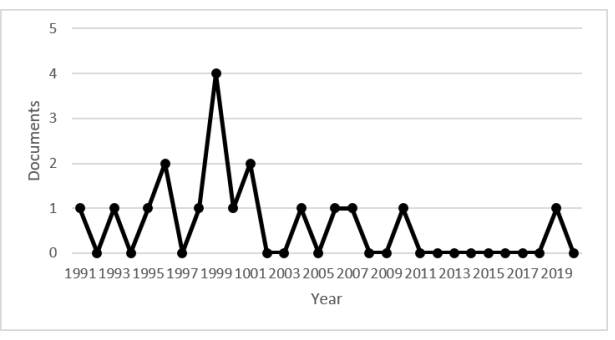

The publications were sorted out as follows: Marketing Intelligence \& Planning topped with 5 publications, followed by Information and Management with 2; International Journal; Decision Support Systems; European Journal of Marketing; Information Management \& Computer Security; International Journal of Electronic Commerce; International Journal of Research in Marketing; Journal of Management Information Systems; Journal of Research in Interactive Marketing; Management Decision; Marketing Intelligence and Planning; Marketing Theory; Strategic Direction with 1 publication each.

In Table 1 we analyze for the Scimago Journal \& Country Rank (SJR), the best quartile and the $\mathrm{H}$ index by publication. The International Journal of Research in Marketing is the most quoted publication with 2.910 (SJR), Q1 and H index 95. There is a total of 8 journals on Q1, 4 journals on Q2 and 1 journals, Q3 and 1 journals on Q4. Journals from best quartile Q1 represent 57\% of the 14

Table 2. Scimago journal \& country rank impact factor

\begin{tabular}{|c|c|c|c|}
\hline Title & SJR & Best Quartile & $H$ index \\
\hline International Journal of Research in Marketing & 2.910 & Q1 & 95 \\
\hline Journal of Management Information Systems & 2.860 & Q1 & 137 \\
\hline Information and Management & 2.400 & Q1 & 153 \\
\hline Decision Support Systems & 1.920 & Q1 & 138 \\
\hline Marketing Theory & 1.660 & Q1 & 62 \\
\hline European Journal of Marketing & 1.030 & Q1 & 91 \\
\hline International Journal of Electronic Commerce & 1.030 & Q1 & 77 \\
\hline Management Decision & 0.860 & Q1 & 91 \\
\hline Journal of Research in Interactive Marketing & 0.760 & Q2 & 31 \\
\hline Marketing Intelligence \& Planning & 0.620 & Q2 & 64 \\
\hline Marketing Intelligence and Planning & 0.620 & Q2 & 64 \\
\hline Information Management \& Computer Security & 0.430 & Q2 & 39 \\
\hline International Journal & 0.180 & Q3 & 19 \\
\hline Strategic Direction & 0.120 & Q4 & 10 \\
\hline
\end{tabular}

Source: own elaboration 
journals titles; best quartile Q2 represents 29\% and finally, best quartile Q3 and Q4 represents 7\% each of the titles of 14 journals

As evident from Table 2, the significant majority of articles on MKIS rank on the Q1 best quartile index.

The subject areas covered by the 19 scientific articles were: Business, Management and Accounting (19); Decision Sciences (6); Computer Science (4); and, Arts and Humanities; Economics, Econometrics and Finance; Psychology; and Social Sciences (1).

The most quoted article was "The impact of individual and managerial factors on salespeople's contribution to marketing intelligence activities" from Le Bon \& Merunka (2006) with 54 quotes published in the International Journal of Research in Marketing with 2.910 (SJR), the best quartile (Q1) and with $\mathrm{H}$ index (95). The published article focuses on studying the motivation and effort of salespeople in gathering and transmitting information intelligence marketing.

In Figure 2 we can analyze the evolution of citations of articles published between 2005 and 2020. The number of citations shows a net positive with 2020 peaking at 333 citations.

Figure 2. evolution of citations between 2005 and 2020 (Source: own elaboration)

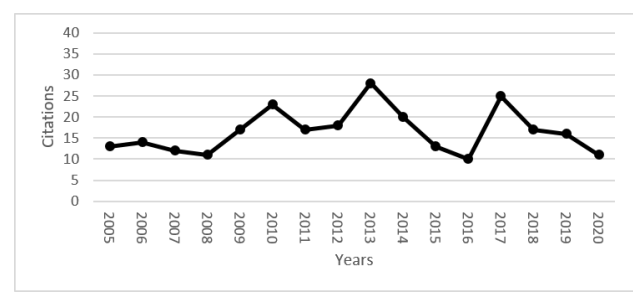

The h-index was used to ascertain the productivity and impact of the published work, based on the largest number of articles included that had at least the same number of citations. Of the documents considered for the h-index, 11 have been cited at least 11 times.

In Annex I, the citations of all scientific articles from the 2005 to 2020 period are analyzed; 5 documents were not cited until 2020, until $\leq 2005,81 ; 2006,14 ; 2007,12 ; 2008,11 ; 2009,17 ; 2010$, 23; 2011, 17; 2012, 18; 2013, 28; 2014, 20 2015, 13; 2016, 10; 2017, 25; 2018, 17; 2019, 16; and 2020,11 , with a total of 333 citations.

Annex II examines the self-citation of the document during the period $\leq 2005$ to 2020,19 documents were self cited 13 times, The impact of individual and managerial factors on salespeople's

Table 3. Documents without quotes until 2020 (2005 - 2020 period)

\begin{tabular}{|l|l|l|c|c|c|}
\hline \multicolumn{1}{|c|}{ Documents } & Investigator & Title & SJR & $\begin{array}{c}\text { Best } \\
\text { Quartile }\end{array}$ & $\begin{array}{c}\text { H } \\
\text { index }\end{array}$ \\
\hline $\begin{array}{l}\text { Effects of enduring involvement and } \\
\text { perceived content vividn... }\end{array}$ & Vazquez (2019) & $\begin{array}{l}\text { Journal of Research in } \\
\text { Interactive Marketing }\end{array}$ & 0.760 & Q2 & 31 \\
\hline $\begin{array}{l}\text { Britannia discovers the benefits of } \\
\text { analytical CRM }\end{array}$ & $-*(2002)$ & Strategic Direction & 0.120 & Q4 & 10 \\
\hline
\end{tabular}

Note: *data not available.

Source: own elaboration 
contribution to marketing intelligence activities (1999) published in Marketing Intelligence \& Planning and Marketing information systems in the fortune 500 companies: Past, present, and future (1993) published in the Journal of Management Information Systems were self-quoted 4.

Of the 19 scientific papers, 2 have not been cited until the time of writing of this paper (Table 3)

\section{THEORETICAL PERSPECTIVES}

An investigation with small and medium-sized companies in Queensland, Australia conducted by Buttert \& Tamaschke (1996) with the main objectives of the researchers is to create a snapshot of the companies 'progress in adopting and implementing MKIS and the managers' recognition of the value of such systems. The study finds that while the recognition of MKIS' value is widespread across both the services and industrial sectors, the surveyed firms had done very little to develop pertinent mechanisms and interventions. Accordingly, the authors respond to the state of affairs by developing seven maxims for the development of a sound MKIS (Butterly \& Tamashcke, 1996). They assert that an effective MKIS must, firstly, be a centralized and unified system. Secondly, it must function as a decision supporting system. It must also be economical, compatible with the organization, useoriented, and needs-based. Lastly, an effective MKIS is fast in communication and is future-oriented.

Additionally, Gounaris, et al. (2007) construct and appraise an empirical instrument designed specifically to measure the effectiveness of MKIS. The foundation of the proposed instrument was an in-depth review of literature, which facilitated the conceptualization of the critical dimensions of MKIS effectiveness. The instrument was subsequently subjected to validating experimentation using data from 254 Grecian five-star hotels, collected by use of pre-tested questionnaires. Gounaris, et al. (2007) find that the primary internal metrics of MKIS efficacy are the degree of improvements it generates in the two domains of corporate climate and functional effectiveness. The authors also demonstrate that the two key external variables of effectiveness are the extent to which the MKIS improves the firm's 'adaptability to market conditions' and the system's contributions to 'customer responsiveness' (Gounaris, et al., 2007). These findings offer essential guidelines that are generalizable across other organizations, but more particularly firms operating within the global hospitality industry, as they were the focus of the research.

Similarly, Chatzipanagiotou \& Coritos (2010) examine the major antecedents to MKIS effectiveness and how these factors impact firms' decision to adopt specific marketing applications. After collecting and analyzing empirical data from 254 five-star and luxury Grecian hotels, the authors find that the most significant of the said antecedents were the hotel's degree of market orientation adoption, system quality, the quality of the information that the MKIS produce, and support service quality (Chatzipanagiotou \& Coritos, 2010). The antecedents aforementioned and their influence on the adoption of specific MKIS enabled the authors to develop a three-pronged empirical typology of the surveyed hotels based on the MKIS configurations, namely market-, sales-, and transactional-oriented hotels. More importantly, the findings of the research provide hoteliers and other businesspeople with an empirical framework for realistically evaluating the benefits likely to accrue from the adoption of specific types of MKIS.

A particularly robust thematic area that emerges from the review of literature consists of empirical studies that preoccupy themselves with the alignment of MKIS with both marketing and overall organizational strategy in real-life practice. An empirical study by Xu (1999) shows that while many companies and marketing managers perceive the strategic function of marketing as important, the application of MKIS does not keep abreast with the current practice of marketing strategic function. To get to the bottom of this state of affairs, Higby \& Farah (1991) conduct a survey on a randomized sample of 2993 marketing professionals in the employ of a select population of American firms. The researchers develop a questionnaire based on an extensive review of marketing literature and then apply it to collect and analyze data requisite for answering two research questions including, firstly, the level of firms' use of MKIS, expert systems (ES), and decision support systems (DSS); 
and, secondly, the degree of each system's application to specific marketing activities. The survey's findings reveal several valuable insights concerning the most feasible application of MKIS for various types of firms. Notably, it finds that organizations that derive the most significant strategic benefits from the application of DSS are 'middle to large size firm(s) (more than 100 employees and annual revenues in excess of $\$ 100$ million)', wherein middle level managers appear to be the most receptive to DSS integration into marketing activities because of the informational advantages that these systems generate (Higby \& Farah, 1991). Customer profile analysis, competitive analysis, market research project design, pricing decisions, and sales forecasting are some of the marketing activities that DSS appeared to support, strongly. Secondly, the research findings suggest that ES application is likely to find support among middle level managers in large firms with annual revenues exceeding \$300 million and more than 1000 employees because of the benefits that these marketing applications introduce to a variety of areas in strategic management, including facility location, sales forecasting, order processing, and inventory control (Higby \& Farah, 1991). The overarching guideline that is retrievable from the reviewed study is that one of the most critical decision variables that contemporary firms are best advised to consider in their approaches to MKIS implementation is the management concerns the strategic information needs of both firms and the managers responsible for various marketing functions therein.

Similarly, Li (1995) undertook survey research to evaluate the attitude toward MKIS of marketing executives in the employ of 500 companies listed in the April 1990 issue of the Fortune magazine. The authors compare their findings to the data generated by previous research with the broader goal of ascertaining the determinants of marketing executives' decisions to utilize specific marketing applications, based on the observable underlying use-case trends. Notable insights from the research derive, firstly, from the fact that the authors found that the majority of Fortune 500 marketing managers cited 'the firm's data processing subsystem which provides internal accounting data as the most important source of (marketing) data and information', followed by marketing research and then marketing intelligence (Li, et al., 1993). Additionally, the research showed that the only area of MKIS application that displayed a downward trend from comparable, earlier periods was mathematical modeling, which posted increments in only two areas of marketing application, namely advertising media selection and product deletion. Given that Fortune 500 companies are conventionally considered to be industry leaders in the adoption and use of information technology, the research by $\mathrm{Li}$, et al. (1993) lends credence to the best practice of considering the strategic informational needs emergent at all levels of strategic marketing management during the firm's implementation of MKIS or any other pertinent component.

Furthermore, $\mathrm{Li}$ (1995) sought to broaden the findings of Li, et al. (1993) that were expounded upon previously by broadening the surveyed population to include the marketing executives of the top 1000 firms listed in a publication by Business Week. The author similarly compares his findings to those generated by comparable empirical research dating to the year 1985 . The findings by $\mathrm{Li}$ (1995) largely replicate those of $\mathrm{Li}$, et al. (1993) exploration of Fortune 500 companies marketing executives. They study shows a significant increment in marketing managers' need for, and utilization of computers, in data retrieval, storage, and processing. It also finds, similarly, that marketing executives consistently perceive internal accounting as the most essential source of MKIS information followed by a balance in importance between marketing research and intelligence. According to the research, moreover, middle-level managers are the major users of MKIS, and most firms focus their data collection efforts on gathering information about customers first and foremost, with some efforts targeted at collecting data about competitors and prospective customers. Additionally, controlling and planning are the management functions with the most frequent use of MKIS support, where product and price related decisions consume the majority of MKIS resources. Finally, modeling through logic programming languages, expert system shells, and logic programming languages is the MKIS application used the most infrequently. 
Lackman, et al. (2000), on the other hand, focus specifically on the MKIS component of marketing intelligence and its contribution to strategic and tactical business decisions. The researchers survey a randomized sample drawn from a robust cross section of firms on the respondents' degree of marketing intelligence data sources, activity, and accountability. $67 \%$ of the respondents reported that marketing intelligence activity added value to competitive and consumer intelligence and $54 \%$ asserted that marketing intelligence's impact is felt heavily at the tactical and strategic levels of decision-making. Although a small minority of the surveyed companies (2\%) perceived marketing intelligence as bearing no significant import for organizational strategy, none reported a reduction in marketplace success owing to the firm's introduction of marketing intelligence activity. Importantly, Lackman, et al. (2000) revealed that the most important marketing intelligence data sources are research and development, manufacturing and customers; and that roughly $50 \%$ of the companies surveyed held their marketing functions accountable for marketing intelligence activity (Lackman, et al., 2000). Broadly, the survey generates useful insights concerning possible ways of aligning MKIS with the broader strategy.

Furthermore, Ashill \& Jobber (2001) test a conceptual framework proposed by the same authors in 1999 concerning the fundamental characteristics of data and information contained in effective MKIS (Ashill \& Jobber, 1999). The authors conduct a series of qualitative interviews with 20 senior marketing managers to determine the information needs of marketing practitioners that should ideally guide the process of designing an effective MKIS. The results of the interviews indicate that the said information needs can be conceptualized by utilizing six information characteristics, namely aggregated marketing information, broad scope marketing information, current marketing information, personal information sources, and impersonal information sources (Ashill \& Jobber, 2001). The findings generate guidelines on the attributes of information that contemporary firms should consider when determining the unique, context-specific informational needs of marketing managers as emergent within their internal environments.

Notably, Hess, et al. (2004) analyze some practical considerations that contemporary firms must face when dealing with issues regarding the strategic alignment of MKIS. The authors focus specifically on the fitting of the MKIS into all aspects of marketing strategy, based on the premise that the marketing decision universe is divided into four separate, yet interlinked and interrelated strategic domains. An effective MKIS, the authors argues, is one that is capable of spanning all of the four domains, yet they observe that 'little guidance on the construction of specific MKIS targeted at problems in these domains or to the construction of integrated MKIS that span domains' is presently available (Hess, et al., 2004). Consequently, the article proposes the geographic information systems (GIS) as a decision support system generator capable of addressing the problem of integrating the elements of MKIS into all domains of a firm's marketing strategy and activity. The research demonstrates, empirically, that the GIS has the unique advantage over other types of MKIS technologies because of 'its ability to integrate information from disparate sources and spanning multiple decision domains when a single decision requires this capability' (Hess et al., 2004). Beyond the specific use case of GIS, more importantly, the article reveals that modern firms are best advised to consider how divergent technological alternatives serve their respective strategic interests and address their internal challenges. For instance, the GIS technology works for all firms but more particularly those that are seeking a mechanism to integrate analyses of their internal and external marketing intelligence data both in a format particularly suited to marketing decision making; and to greatly improve the effectiveness of these marketing decisions (Hess et al., 2004).

Another broadening and developing group of studies dealing with the research topic on the implications of MKIS for contemporary businesses consists of those that focus specifically on the question of the role of MKIS in marketing and advertising in the age of the Internet. This paper reviews three of such articles. Heinen (1996) explores current and potential use cases of Internet-based MKIS. The author offers marketing professionals practical lessons in matching and customizing their 
MKIS resources to their customers needs. The most compelling use case the author elaborates, in this regard, is the application of Internet-based MKIS as tools for gathering marketing information.

Similarly, Rowley (1999) addresses the question of how customer and transaction data collected through electronic and e-shopping over the Internet can be fully utilized. The article thus explores the literature available on the development of customer databases as a MKIS tool in marketing. The author establishes that e-shopping in contemporary marketing practice is increasingly defined by the supplanting of human service agents from the value chain by computers. This dynamic facilitates a superior gathering of both quantitative and qualitative customer and transaction data. The overarching finding is that companies can leverage these data in informing tactical, operational, and strategic decision-making, and in developing more meaningful relationships with customers.

Moreover, Vazquez (2019) focuses on a specific implication of the integration of marketing and MKIS, namely the effects of enduring involvement and perceived content vividness on digital engagement. The author compares the impact of perceived content vividness against enduring involvement with products on digital engagement. Through quasi-experiments with brand communities on social media, the article finds that enduring involvement with products generates higher and more sustained digital engagement than perceived content vividness. The implication for marketing practitioners is, therefore, that they should focus their MKIS efforts more on product involvement than content vividness. More importantly, the research shows some of the developing and evolving conditions that contemporary firms encounter as the Internet increasingly alters the operating environments of modern MKIS.

An additional school of thought emergent within the extant body of literature on MKIS concerns the increasing role of its 'marketing intelligence' component in contemporary marketing practice and the ambiguities thereof. In its case study of the application of MKIS by the Britannia Building Society, Strategic Direction (2002) emphasizes that the primary focus of a firm's marketing intelligence activity should be to determine consumer behavior by emphasizing an in-depth understanding of the customer. This is in stark contrast to the postulations of Marsden (1998) whose study of memeticsthe science of memes- suggests that such an approach to the application of marketing intelligence in understanding consumer behavior is a dead end. Marsden (1998) argues that from the perspective of memetics, "a prerequisite for understanding customer behavior is the ability to audit and understand the infection strategies of the particular memes that are resident in our brains" (Marsden, 1998, p. 365). Such competing perspectives emergent from both practitioner and academic marketing research reflect the reality that contemporary firms face in their decision-making concerning the best use of scarce MKIS resources.

$\mathrm{Li}$, et al. (1999) also find that the current applications of computer-based information systems to support firms' efforts of developing marketing strategies are, in practice, found to be less than satisfactory in terms of resolving the ambiguities generated by extant and emerging paradigms of marketing intelligence. Moreover, the authors observe that the literature presently available is largely silent on the appropriate guidelines for companies interested in implementing effective marketing intelligence. The article, thus, proposes a hybrid intelligent support system for developing marketing strategy (Li, et al. 1999), thereby highlighting some of the generic and specific guidelines that firms can adopt to navigate the convolutions that marketing intelligence and MKIS, in general, may present in practice.

An important piece of insight generated by the aforementioned hybrid model proposed by Li, et al. (1999) is that an effective implementation of even the best marketing intelligence system is largely dependent on 'individual managers' experience, knowledge, and skills in developing marketing strategy and 'strategic marketing planning'. Le Bon \& Merunka (2006) also find that individual and managerial factors influence the motivation and behavioral disposition of salespeople towards operations and activities of marketing intelligence. These individual factors constitute another important consideration that firms must make when taking decisions concerning the adoption and implementation of MKIS. 
The impacts of MKIS on the firm and on the relationship between and among firms, beyond the effects specific to the marketing function, is also another important research theme that emerges from this paper's review of literature. Watson \& McKeown (1999) explores the said impact from the perspective of inter-organizational systems (IOS), namely a networked information system used by two or more separate organizations to perform a joint business function. The authors find that contemporary firms operating in the age of the Internet have significant opportunities to leverage their MKIS in achieving robust IOSs, given that Internet-based MKIS facilitate IOSs by overcoming previous cost barriers to establishing inter-organizational connections, and to switching from traditional electronic data interchange to IOS. Additionally, McIntyre \& Sutherland (2002) critically analyze the impact MKIS on firm-level accumulation of marketing knowledge. The authors identify four primary sources of impediments to the contribution of MKIS toward the accumulation of marketing knowledge, namely the price to be paid by different components of the organization responsible for the MKIS implementation; the marketing plan and the strategies contained therein; internal communications; and the distribution channels underlying the operation of the MKIS. Each of the areas aforementioned demands specific attention by firms evaluating or considering adopting MKIS.

\section{DISCUSSION OF THEMES}

As indicated at the beginning of the paper, this discussion's overarching objective is to derive a set of concise guidelines for MKIS in the context of contemporary firms. Five broad thematic areas emerge from this research, in this regard, namely guidelines on: (i) developing, implementing, and measuring the effectiveness of MKIS; (ii) how to align MKIS with organizational strategy and decision-making; (iii) leveraging MKIS capabilities in Internet marketing; (iv) generating and applying marketing intelligence; and (v) leveraging MKIS benefits in terms of marketing knowledge accumulation and marketing intelligence.

Regarding issues relating to the development, implementation, and effectiveness of MKIS, contemporary firms are best advised to focus system development around the attributes of unification and centralization, effective decision support capabilities, compatibility with the organization, costvalue ratio acceptability, communication speed and efficiency, future orientation, user-orientation, and needs-based foundation. The design, development, and implementation of MKIS should also center upon specific considerations of the major antecedents to system effectiveness, namely the quality of the system, the quality of the information the system generates, and the quality of support the system accords to the firm's service delivery. Moreover, contemporary firms are well served by measuring the effectiveness of their respective MKISs based on an evaluation of the said system's addition to the firm's corporate climate and functional effectiveness, and its contribution towards the firm's customer responsiveness and adaptability to market conditions.

Regarding the guidelines on the strategic alignment of MKIS, contemporary firms should ideally address three sets of decision domains, each with strategic, tactical, and operational considerations, respectively. The domain with strategic considerations contains decision variables appertaining to size of the firm and the general direction of the industry. As the review of literature demonstrates, different sizes of firms derive varying degrees of benefits from various MKIS with divergent core areas of emphasis depending on the firms' size. The direction of the industry is also a useful metric of the feasibility of different approaches to the use of MKIS by comparable firms. From a tactical perspective, a crucial consideration concerns the need to match unique organizational contexts with the appropriate technology. The example provided herein on the application of the GIS DSS offers a compelling narrative of why it is important to select MKIS technologies based on the firm's respective strategic needs. From an operational perspective, the most important issue that modern firms must address in their MKIS activities pertains to the sources of system information and data.

Thirdly, contemporary firms are best advised to pay specific attention on the evolving influence of Internet marketing on the operationalization of MKIS. Of utmost importance is the need to consider 
the various novel opportunities that the Internet environment presents such as in information gathering and consumer centrism. The emerging, practical implications of the Internet for specific MKIS marketing applications, evidenced herein by the competing priorities between product involvement and content vividness, are also crucial areas of consideration.

Fourthly, contemporary firms can resolve issues of ambiguities in the discipline and practice of marketing intelligence by adopting hybrid intelligent support system frameworks into their respective processes of developing marketing strategy. Such an approach allows the firm's marketing intelligence activities to meet several fundamental objectives, including aiding strategic thinking and analysis and integrating the strengths of diverse support technologies and techniques. A hybrid system also has the additional benefits of combining the advantages of different models of strategic analysis coupling managers' judgment with strategic analysis.

Finally, efforts by modern firms to implement MKIS should be underpinned by keen attention paid to the firm-level and inter-organizational impacts of the system. Specifically, organizations should prioritize the process of identifying and eliminating the barriers to the contributions of MKIS towards the accumulation of firm-level, internal marketing knowledge. Additionally, firms can bolster their competitive advantages by leveraging the benefits that MKIS offer in enhancing the relationships between organizations, particularly through the implementation of effective IOS by aid of Internet technologies.

\section{CONCLUSION}

The extant body of literature on marketing information systems is robust. Despite this abundance of knowledge, however, there appears to a glaring gap in the studies that specifically seek to generate guidelines that contemporary firms can utilize to better implement their MKIS and realize the substantial benefits posited within the available literature. The main conclusions of the study conclude that companies are better prepared in the development, implementation and measurement of the MKIS, contributing to an analysis of the client, providing an efficient response and providing the company with conditions of adaptability in the market. The strategic alignment of the MKIS should be approached from the field of decision, strategic conditions and operational tactics. With companies taking into account the practical implications of the internet in the operationalization of MKIS marketing, customer and market understanding. The implementation of marketing intelligence or a hybrid system can provide the development of strategic thinking, providing the identification of possible competitive advantages. Companies and managers should implement and disseminate the advantages of MKIS marketing, highlighting the contributions in strengthening or identifying competitive advantages.

The review undertaken herein has attempted to address the identified gap by synthesizing the scarce and disparate theoretical/empirical studies on the question of interest. Additional research is necessary to test the feasibility of each of the review's recommended (development, implementation and measurement of MKIS effectiveness; how to align MKIS with organizational strategy and decision making; leveraging MKIS resources in Internet marketing; generation and application of marketing intelligence; and how to leverage the benefits of MKIS in terms of knowledge accumulation and marketing intelligence) guidelines in the unique and specific settings of different types of organizations, industries, sectors, and business environments.

\section{ACKNOWLEDGMENT}

We would like to express our gratitude to the Editor and the Referees. They offered extremely valuable suggestions or improvements. The author were supported by the GOVCOPP Research Center of Universidade de Aveiro. 


\section{REFERENCES}

Ashill, N., \& Jobber, D. (1999). The impact of environmental uncertainty perceptions, decision-maker characteristics and work environment characteristics on the perceived usefulness of marketing information systems (MkIS): A conceptual framework. Journal of Marketing Management, 15(6), 519-540. doi:10.1362/026725799785045815

Ashill, N. J., \& Jobber, D. (2001). Defining the information needs of senior marketing executives: An exploratory study. Qualitative Market Research, 4(1), 52-61. doi:10.1108/13522750110364578

Ashmarina, S., \& Zotova, A. (2016). The system of marketing information management: development, assessment, improvement. doi:10.21003/ea.V160-10

Britannia discovers the benefits of analytical CRM. (2002). Strategic Direction, 18(11), 20-23. doi: $10.1108 / 02580540210794120$

Buttery, A., \& Tamaschke, R. (1996). The use and development of marketing information systems in queensland, australia. Marketing Intelligence \& Planning, 14(3), 29-35. doi:10.1108/02634509610117339

Chatzipanagiotou, K. C., \& Coritos, C. D. (2010). A suggested typology of greek upscale hotels based on their MrkIS: Implications for hotels' overall effectiveness. European Journal of Marketing, 44(11), 1576-1611. doi:10.1108/03090561011079800

Gounaris, S. P., Panigyrakis, G. G., \& Chatzipanagiotou, K. C. (2007). Measuring the effectiveness of marketing information systems: An empirically validated instrument. Marketing Intelligence \& Planning, 25(6), 612-631. doi:10.1108/02634500710819978

Heinen, J. (1996). Internet marketing practices. Information Management \& Computer Security, 4(5), 7-14. doi:10.1108/09685229610153120

Hess, R. L., Rubin, R. S., \& West, L. A. Jr. (2004). Geographic information systems as a marketing information system technology. Decision Support Systems, 38(2), 197-212. doi:10.1016/S0167-9236(03)00102-7

Higby, M. A., \& Farah, B. N. (1991). The status of marketing information systems, decision support systems and expert systems in the marketing function of U.S. firms. Information \& Management, 20(1), 29-35. doi:10.1016/0378-7206(91)90025-W

Lackman, C., Saban, K., \& Lanasa, J. (2000). The contribution of market intelligence to tactical and strategic business decisions. Marketing Intelligence \& Planning, 18(1), 6-9. doi:10.1108/02634500010308530

Le Bon, J., \& Merunka, D. (2006). The impact of individual and managerial factors on salespeople's contribution to marketing intelligence activities. International Journal of Research in Marketing, 23(4), 395-408. doi:10.1016/j. ijresmar.2006.10.002

Li, E. Y. (1995). Marketing information systems in the top U.S. companies: A longitudinal analysis. Information \& Management, 28(1), 13-31. doi:10.1016/0378-7206(94)00030-M

Li, E. Y., Mcleod, R. Jr, \& Roul'rs, J. C. (1993). Marketing information systems in the fortune 500 companies: Past, present, and future. Journal of Management Information Systems, 10(1), 165-192. doi:10.1080/0742122 2.1993.11517995

Li, S., Duan, Y., Kinman, R., \& Edwards, J. S. (1999). A framework for a hybrid intelligent system in support of marketing strategy development. Marketing Intelligence \& Planning, 17(2), 70-79. doi:10.1108/02634509910260922

Mandal, P. C. (2018). Marketing information and marketing intelligence: Roles in generating customer insights. International Journal of Business Forecasting and Marketing Intelligence, 4(3), 311-321. doi:10.1504/ IJBFMI.2018.092786

Marsden, P. S. (1998). Memetics: A new paradigm for understanding customer behaviour and influence. Marketing Intelligence \& Planning, 16(6), 363-368. doi:10.1108/EUM0000000004541

Martell, D. A. (2018). Marketing information and new technology. In Management information systems: The technology challenge (pp. 161-181). Routledge. doi:10.4324/9781351131872.ch8 
McIntyre, S. H., \& Sutherland, M. (2002). A critical analysis into the accumulation of marketing knowledge at the level of the firm. Marketing Theory, 2(4), 403-418. doi:10.1177/147059310200200409

Perreault, W. D. (2018). Essentials of marketing. Mc Graw Hill.

Rosário, A., \& Cruz, R. (2019). Determinants of Innovation in Digital Marketing, Innovation Policy and Trends in the Digital Age. Journal of Reviews on Global Economics, 8, 1722-1731. doi:10.6000/1929-7092.2019.08.154

Rosário, A. T., Vilaça, F., Raimundo, R., \& Cruz, R. N. (2020). Determinants of nascent entrepreneurship development. In A. C. Moreira \& J. Dantas (Eds.), Challenges to Nascent Entrepreneurship and Creating New Ventures. IGI Global. doi:10.4018/978-1-7998-4826-4.ch008

Rowley, J. (1999). Loyalty, the internet and the weather: The changing nature of marketing information systems? Management Decision, 37(6), 514-519. doi:10.1108/00251749910278032

Sacavém, A., Cruz, R., Sousa, M., \& Rosário, A. (2019). An integrative literature review on leadership models for innovative organizations, innovation policy and trends in the digital age. Journal of Reviews on Global Economics, 8, 1741-1751. doi:10.6000/1929-7092.2019.08.156

Sigauke, I. (2019). A conceptual framework on optimizing the use of marketing information. International Forum Journal, 22(1), 34-45.

Vazquez, E. E. (2019). Effects of enduring involvement and perceived content vividness on digital engagement. Journal of Research in Interactive Marketing, 14(1), 1-16. doi:10.1108/JRIM-05-2018-0071

Wahyuni, P., \& Lestari, P. N. E. (2020). Application of web-based customer relationship management in marketing information system: PT. BPR Bali Dananiaga. International Research Journal of Management. IT and Social Sciences, 7(4), 43-47. doi:10.21744/irjmis.v7n4.947

Watson, R. T., \& McKeown, P. G. (1999). Manheim auctions: Transforming interorganizational relationships with an extranet. International Journal of Electronic Commerce, 3(4), 29-46. doi:10.1080/10864415.1999.11518347

Xu, X. M. (1999). The strategic orientation of marketing information systems - an empirical study. Marketing Intelligence \& Planning, 17(6), 262-272. doi:10.1108/02634509910293070 


\section{APPENDIX I.}

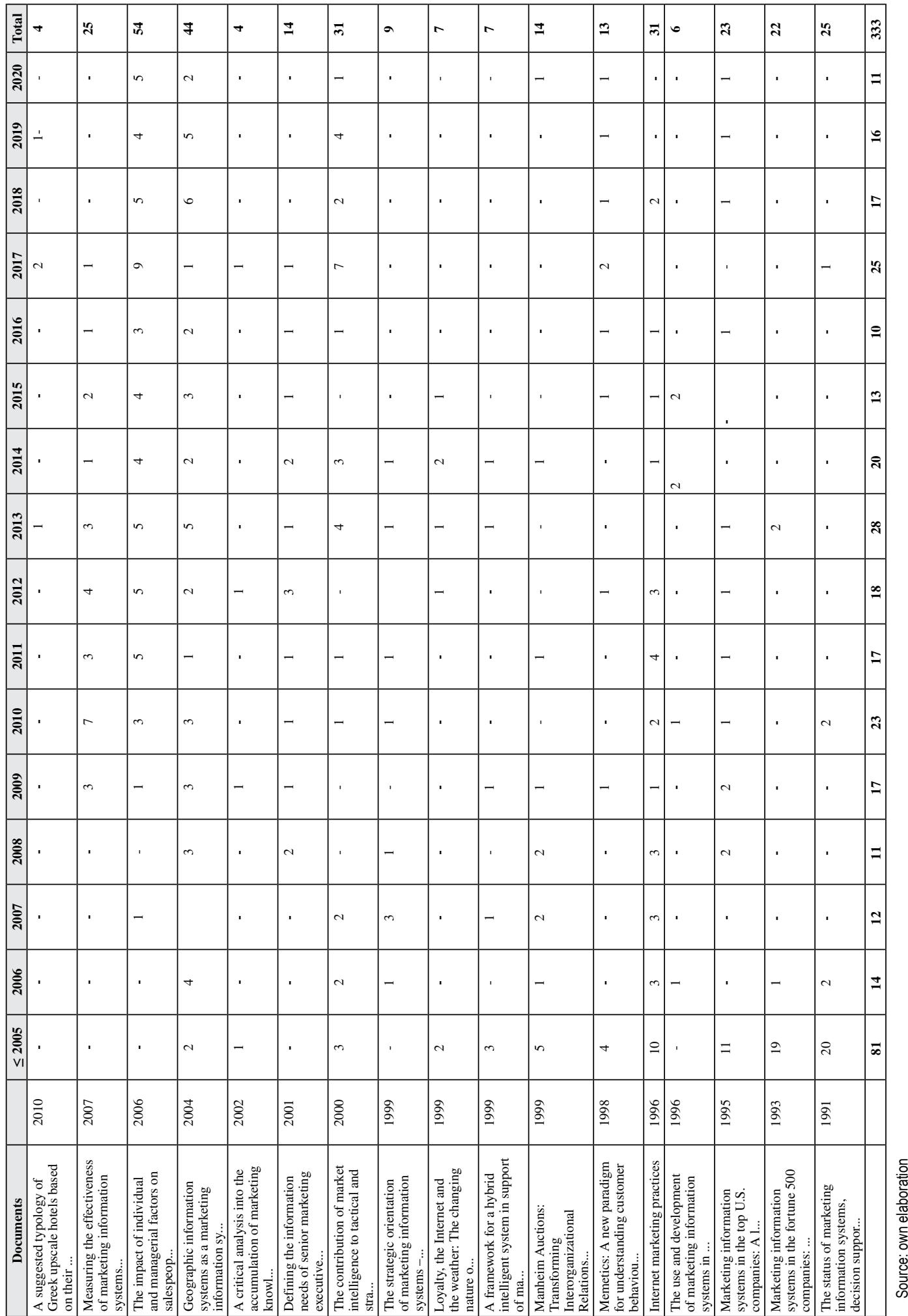




\begin{tabular}{|c|c|c|c|c|c|c|}
\hline 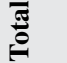 & - & - & $\nabla$ & $m$ & $\nabla$ & 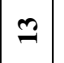 \\
\hline ત્సิ & I & ' & I & ' & I & ' \\
\hline 록 & ' & ' & ' & ' & ' & ' \\
\hline 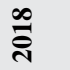 & ' & ' & ' & ' & I & ' \\
\hline 공 & ' & ' & ' & ' & , & . \\
\hline ํㅜㄱ & ' & ' & ' & ' & ' & ' \\
\hline ำ & ' & ' & ' & . & ' & ' \\
\hline 곡 & ' & ' & 1 & ' & ' & ' \\
\hline 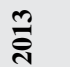 & ' & - & ' & ' & ' & - \\
\hline 곡 & ' & ' & ' & ' & ' & ' \\
\hline$\overline{\overline{\mathrm{N}}}$ & ' & ' & ' & ' & ' & . \\
\hline 옥 & - & ' & 1 & ' & ' & - \\
\hline હิે్ & ' & ' & ' & ' & ' & ' \\
\hline$\stackrel{\infty}{\circ}$ & ' & ' & ' & ' & ' & ' \\
\hline స్ & ' & ' & - & ' & ' & - \\
\hline ڤ్సે & ' & ' & & ' & ' & ' \\
\hline VI & 1 & ' & $m$ & $m$ & $\nabla$ & $\Theta$ \\
\hline & 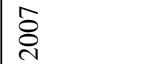 & ષ્ర & ڤे & $\stackrel{2}{\Omega}$ & $\stackrel{\Omega}{\sigma}$ & \\
\hline 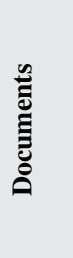 & 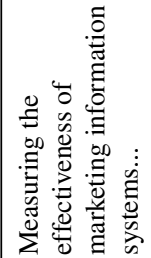 & 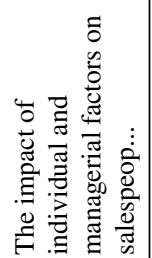 & 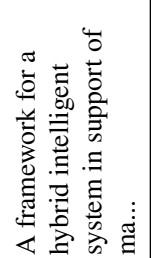 & 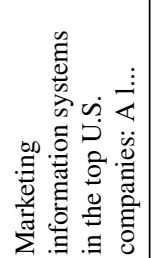 & 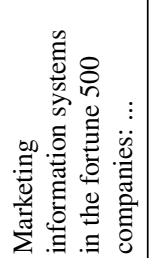 & \\
\hline
\end{tabular}


Albérico Travassos Rosário, Ph.D. Marketing and Strategy of the Universities of Aveiro (UA), Minho (UM) and Beira Interior (UBI). With affiliation to the GOVCOPP research center of the University of Aveiro. Master in Marketing and Degree in Marketing, Advertising and Public Relations, degree from ISLA Campus Lisbon - European University | Laureate International Universities. Has the title of Marketing Specialist and teaches with the category Assistant Professor at the School of Management and Technology of Santarém (ESGTS) Polytechnic Institute of Santarém, Assistant Professor IPAM - School of Marketing | Laureate International Universities. He taught at ISLA - Instituto Superior de Gestão e Administracao de Santarém (ISLA-Santarém), was Director of the Commercial Management Course, Director of the Professional Technical Course (TeSP) of Sales and Commercial Management, Chairman of the Pedagogical Council and Member of the Technical Council and ISLA-Santarém Scientific Researcher. He is also a marketing and strategy consultant for SMEs. Her main research interests are: Competitive Strategy, Competitive Dynamics, Strategic Groups and Marketing. 